\title{
Effect of Cirripedia sp. Flour As Subtitutional Feed Source of Protein Against Dried Disease and Organic Material Rabbit Rain Type Rex
}

\author{
Bodhi Agustono $^{1}$, Widya Paramita Lokapirnasari ${ }^{1}$, Moh. Anam Al Arif ${ }^{1}$, \\ Ragil Angga Prastiya ${ }^{2}$, Faisal Fikri ${ }^{3}$ \\ ${ }^{1}$ Department of Animal Husbandry, ${ }^{2}$ Department of Veterinary Reproduction, \\ ${ }^{3}$ Department of Basic Veterinary Medicine Veterinary Medicine Faculty, Airlangga \\ University Campus C UNAIR Mulyorejo, Surabaya, East Java, Indonesia 60115 \\ Corresponding author: bodhiagustono@fkh.unair.ac.id
}

\begin{abstract}
The aim of this research was to determine the effect of Cirripedia $s p$. flour as feed substitution of protein source in feed on the digestibility of dry matter and organic matter in 100 male rex broilers. The research was experimental by using a completely randomized design with four treatments and five replications. Substitution of Cirripedia $s p$. flour respectively in feed were $0 \%, 2.5 \%, 5 \%, 7.5 \%$ given for four weeks. Data collection was carried out in the fourth week (for seven days) which included consumption data, manure weight and analysis of treatment feed and manure analysis. The data were analyzed using Analysis of Variance and the difference between treatments was determined by the Duncan test. The results showed that there was no significant difference $(p>0.05)$ and that there was no significant difference $(p>0.05)$ on the digestibility of rex broilers. This shows that the substitution of Cirripedia sp. flour in feed can replace animal protein sources in fish meal in complete feed rabbits.
\end{abstract}

Key words : Cirripedia sp, digestibility, feed subtitution, flour, rabbit.

\section{Introduction}

Increased food production is an effort to ensure the fulfillment of nutritional needs for the community, especially animal protein needs. Rabbit farming is one type of cultivation that is not rapidly developing like other livestock businesses such as chickens and ruminants. This is due to the lack of public knowledge about the economic value or what products can be produced from rabbits (Ridwan and Asnawi, 2008).

Rabbit or in another language is called Oryctolagus cuniculus is one of the pseudo-ruminant animals which is quite good in productivity. In general rabbits have a litter size of 1-8 tails per year, and in one year rabbits are able to give birth up to 8 times (Raharjo and Brahmantiyo, 2014). In addition, rabbit meat contains $18.7 \%$ protein composition, $6.2 \%$ lower fat, when compared with cow fat which can reach $18.3 \%$ while lamb fat $17.5 \%$ (Rukhmana, 2005). Rabbit carcass weight around 50\% - 60\% of live weight (Sarwono, 2004). Several factors that support the advantages and benefits of rabbit cultivation include maintenance management, management of the cage and good feed management and are suitable for rabbit needs.

Feed is a basic life necessity for livestock that can support and enhance growth and reproduction. Feed given to rabbits that are kept intensively is $60 \%$ in the form of forage and $40 \%$ in the form of concentrate (Wijayanti, 2009). Feed must have protein, fat, carbohydrate, mineral, vitamin and water content (Subekti, 2009). Suprijatna et al. (2005) state that efficient production will be achieved if cheap feed is available and high 
efficiency values (palatability, consumption and high digestibility). Putri et al. (2013) states that the digestibility of dry matter and the digestibility of organic matter is one of the important parameters in the use of feed. Increased digestibility of feed ingredients and nutrients in the body of cattle will produce maximum livestock production (Putri e al., 2013). One of the feed ingredients that meets the above requirements and has great potential as an alternative feed is Cirripedia sp. Flour.

Cirripedia sp. is a coastal animal that has great potential as an alternative feed for animals with abundant quantities and low prices. Utilization of Cirripedia sp. by the community, especially those who live in the area around the coast are still few. According to (Rahmaningtyas et al. 2017) Cirripedia sp. has some ingredient, including dry matter $87.79 \%$; crude fat $13.51 \%$; crude protein $46.56 \%$; crude fiber 3.54\%; ash 22.27\%; BETN 1.88\%; Ca 7.27\%; and ME $2602.90 \mathrm{Kcal} / \mathrm{kg}$. The high protein content can be utilized as a feed substitute or substitute for protein source ingredients in rabbit cattle rations such as fish meal. Based on the data of this research is expected that Cirripedia sp. Flour can be a source of protein substitute for fish meal in rabbit feed.

\section{Materials and Methods}

The experimental animals that is used in this research were Rex male rabbits aged between three to four months as many as 100 animals with an average body weight of \pm 850 grams. The experimental animals were used divided into four treatments, each treatment consisting of five animals. The research material used is complete feed with a concentration of T0 (15\% Fish Flour), T1 (12.5\% Fish Flour $+2.5 \%$ Cirripedia sp. Flour), T2 (10\% Fish Flour $+5 \%$ Cirripedia Sp Flour). ), T3 (7.5\% Fish Flour $+7.5 \%$ Cirripedia Flour sp.). Drinking water uses water that comes from refill water. Disinfectants are used to sterilize cages and enclosure equipment before conducting research. The cages used in this study are individual rabbit cages made of length $x$ width $\times$ height $=60 \times 40 \times 40 \mathrm{~cm}$. Each bulkhead is filled with one rabbit. Tool used to carry out proximate analysis of dry matter and organic matter. Dry material analysis requires tools including porcelain (aluminum) cups, cruss pliers, analytical scales, ovens and exicators containing silica gel, whereas for organic matter analysis only formula calculations are required (Al-Arif et al., 2016).

The adaptation period for rabbits is 10 days by giving grass and concentrate feed. This feed composition during the adaptation period for 10 days in a row are $10 \%, 20 \%$, $30 \%$ to $100 \%$. The adaptation period aims to ensure that the rabbit eats the treatment feed to normal according to the treatment given and eliminates the effects of the previous treatment. Rabbits are kept for 4 weeks. Provision of pellets twice a day 06.0007.00 morning and afternoon 17.00-18.00 WIB with a total of at least $160 \mathrm{~g} /$ day and added 5-10 $\mathrm{g}$ for calculation purposes. Drinking water is given ad libitum.

The stool collection and retrieval of food left over is done in the fourth week for 7 days every morning. For each treatment that has dried on the first day to the seventh day was tested by proximate analysis. Digestion calculation uses formula calculation with data taken from the total collection in the period of feces collection and feed consumption which is carried out for 7 days. Determination of the digestibility of dry matter and organic matter is done by proximate analysis test. 


\section{Dry Matter Digestibility}

Dry matter digestibility is obtained from the difference between Consumption of dry material and stool dry material then divided into consumption of dry material and the result is multiplied by $100 \%$. Therefore we need data on consumption of dry material obtained from the difference between the feed given times the dry material feed and the rest of the food times the stool dry material. Organic matter digestibility is obtained from the difference between consumption of organic material and stool dry material then divided to consumption of organic material and the result is multiplied by $100 \%$. Therefore we need consumption of organic material data obtained from the difference between the feed given times the feed organic material and the remaining feed times the feces organic material. Data obtained in this study were analyzed by statistical methods using Variant Analysis or usually called Anova, then followed by Duncan's Multiple Range Test with a significance level of 5\% to determine good treatment (Kusriningrum, 2008).

\section{Dry Matter Digestibility}

\section{Results and Discussion}

The fifth week of this research obtained the results of fish meal substitution using Cirripedia sp. Flour to the digestibility of dry matter of rex male broilers are listed in Table 1.

Table 1. Average and standard deviation of dry matter digestibility of rex male broilers in fish meal substitution using Cirripedia sp. Flour. (\%)

\begin{tabular}{lc}
\hline Treatment group & $\begin{array}{l}\text { Dry matter digestibility } \\
\text { Average } \pm \text { sd }\end{array}$ \\
\hline T0 [100\% complete feed $(15 \% \mathrm{TI})]$ & $73.35 \pm 1.40$ \\
T1 [100\% complete feed $(12.5 \% \mathrm{TI}+2.5 \% \mathrm{TT})]$ & $73.29 \pm 0.52$ \\
T2 [100\% complete feed $(10 \% \mathrm{TI}+5 \% \mathrm{TT})]$ & $73.33 \pm 0.47$ \\
T3 [100\% complete feed $(7.5 \% \mathrm{TI}+7.5 \% \mathrm{TT})]$ & $73.73 \pm 1.44$ \\
\hline ns $=$ non significant, The same superscript in the same column show that is no real difference (p> \\
0.05). TI = Fish Flour. TT = Cirripedia Flour sp.
\end{tabular}

The dry matter digestibility in each treatment $\mathrm{T} 0, \mathrm{~T} 1, \mathrm{~T} 2$ and $\mathrm{T} 3$ respectively were $73.35 \%, 73.29 \%, 73.33 \%$ and $73.33 \%$. Digestibility in this research can be said to be high according to the opinion of Harahap (2011) who argues that nutrient digestibility can be said to be high if the value is equal to or more than $70 \%$ and can be said to be low or moderate if the value is less than $70 \%$. The level of digestibility will determine whether or not the nutrients contained in feed ingredients can potentially be utilized for livestock production. Boangmanalu et al. (2016) added that the digestibility of a feed ingredient is a reflection of the high or low value of the benefits of the feed ingredients. If the percentage of digestibility is high, the benefit value is high and if the percentage of digestibility is low, the benefit value is low (Boangmanalu et al., 2016).

Pridiana (2014) states the level of digestibility of dry matter can be influenced by the consumption of treatment feed and the chemical composition of the treatment feed. Chemical composition of feed can be determined through proximate analysis test. The results of the proximate analysis of feed dry matter for each treatment T0, T1, T2 and 
T3 respectively were $90.00 \%, 90.54 \%, 90.13 \%$ and $90.06 \%$. Proximate analysis data of dry matter of feed each treatment has a little difference and in the same range. This is probably one of the factors that causes no real difference in the digestibility of dry matter in the treatment of fish meal substitution using Cirripedia sp. Flour. to the digestibility of rex dried broilers. This is in accordance with the statement of Tilman et al. (1998) which states that the content of feed composition is one of the factors that can affect the digestibility of feed.

Bidura (2017) states that the nutritional content in feed must be in accordance with the standard needs of livestock. Lack of nutritional content can be increased by using substitute feed ingredients or feed substitution. Feed substitution by replacing part of the feed ingredients with feed ingredients that have the same or more nutritional content in the hope of improving or maintaining the quality and digestibility of a feed. Wardani (2012) shows that the use of rice flour as a food substitution there is no significant difference in the level of digestibility in broilers, as well as the use of Cirripedia sp. Flour as a substitute for fish meal, there was no significant difference in the digestibility of rex dried broilers. Digestion results that do not show a real difference can be interpreted that the use of a feed ingredient as feed replacement or feed substitution can maintain the digestibility of an animal.

\section{Organic Matter Digestibility}

The fifth week of the research obtained the results of the substitution of fish meal using Cirripedia sp. Flour on the digestibility of rex broilers in the organic matter types are listed in Table 2.

Table 2. Average and standard deviation of digestibility of rex organic broilers in fish meal substitution using Cirripedia sp. Flour. (\%)

\begin{tabular}{lc}
\hline Treatment group & $\begin{array}{c}\text { Organic matter digestibility } \\
\text { Average } \pm \text { sd }\end{array}$ \\
\hline T0 [100\% complete feed $(15 \% \mathrm{TI})]$ & $75.42 \pm 1.45$ \\
T1 $[100 \%$ complete feed $(12.5 \% \mathrm{TI}+2.5 \% \mathrm{TT})]$ & $75.98 \pm 0.39$ \\
T2 [100\% complete feed $(10 \% \mathrm{TI}+5 \% \mathrm{TT})]$ & $75.40 \pm 0.67$ \\
T3 [100\% complete feed $(7.5 \% \mathrm{TI}+7.5 \% \mathrm{TT})]$ & $76.88 \pm 1.24$ \\
\hline ns= non significant, The same superscript in the same column show that is no real difference (p $>$ \\
0.05). TI = Fish Flour. TT = Cirripedia Flour sp.
\end{tabular}

Data from the proximate analysis of feed organic material for each research treatment group was T0 75.42\%, T1 75.98\%, T2 75.40\% and T3 76.88\%. Organic matter is obtained from the reduction of dry matter with ash content (Al-Arif, et al., 2016). The reduction results are useful for calculating the digestibility of organic matter using formulas. Fish meal and Cirripedia sp. the proximate analysis showed that ash content was not much different. Ash content that is not much different is likely as one of the factors there is no real difference in the digestibility of organic matter in the treatment of fish meal substitution using Cirripedia sp. Flour to the digestibility of rex.

The absence of a real difference in the digestibility of organic matter can be due to the protein content of fish meal (TI) and Cirripedia sp. Flour. (TT) is not much different, so the substitution of fish meal using Cirripedia sp. Flour. did not have a 
significant effect in increasing the digestibility of rex organic broilers. The composition of the feed composition that is not much different can be the cause of the absence of a real difference in the digestibility of organic matter. This is consistent with the opinion of Surbakti et al. (2014) who argue that the chemical composition of the feed of each treatment can affect the digestibility of feed. The digestibility of a feed depends on the quality of nutrients contained in the feed so that it affects the growth of microorganisms. The digestibility value of a feed depends on the harmony of the food substances contained in it (Surbakti et al., 2014).

The Organic matter digestibility that is not significantly different can also be caused by digestibility of dry matter which is not significantly different. This statement is in accordance with the statements of Tilman et al. (1998) which states that the digestibility of dry matter and organic matter are interrelated, so the higher the percentage of dry matter digestibility will be followed by an increase in the percentage of organic matter digestibility. The high digestibility of dry matter in research led to the high digestibility of organic matter. Rohimah (2012) also mentioned that the digestibility of organic matter will be in line with the digestibility of dry matter, because organic matter is the largest component in dry matter consisting of crude protein, crude fiber, crude fat and Extract Material without Nitrogen (BETN).

\section{Conclusion}

Based on the results of this research, the researcher can be concluded that: Substitution of fish meal using Cirripedia sp. Flour no effect on digestibility of rex dried broilers and substitution of fish meal using Cirripedia sp. Flour has no effect on the digestibility of rex.

\section{References}

Al-Arif, M. A., T. Nurhajati, R. Sidik, M. Lamid, H. Setyono dan W. P. Lokapirnasari. 2016. Buku Ajar Teknologi Pakan Hewan. Fakultas Kedokteran Hewan. Universitas Airlangga.

Bidura, I.G.N.G. 2017. Buku Ajar Limbah Pakan Ternak. Fakultas Peternakan. Universitas Udayana. Denpasar.

Boangmanalu, R., T. H. Wahyuni dan S. Umar. 2016. Kecernaan Bahan Kering, Bahan Organik dan Protein Kasar Ransum yang Mengandung Tepung Limbah Ikan Gabus Pasir (Butis amboinensis) sebagai Substitusi Tepung Ikan pada Broiler. Jurnal Peternakan Integratif. 4(3): 329-340.

Harahap, Y. P. 2011. Pelepah dan Daun Kelapa Sawit Terfermentasi oleh Aspergillus niger dalam Konsentrat terhadap Kecernaan Bahan Kering dan Bahan Organik Ransum pada Sabi Bali (Bos sondaicus) [Skripsi]. Fakultas Pertanian. Universitas Sumatera Utara.

Kusriningrum. 2008. Dasar Perancangan Percobaan dan Rancangan Acak Lengkap. Fakultas Kedokteran Hewan. Universitas Airlangga. Surabaya.

Pridiana E. 2014. Pemanfaatan Limbah Kulit Pisang Kepok Kuning (Musabalbisiana) sebagai Pakan Tambahan terhadap Kecernaan Serat Kasar dan Bahan Organik Ayam Pedaging Jantan [Skripsi]. Fakultas Kedokteran Hewan. Universitas Airlangga. Hal. 32. 
Putri, F. J., F. Sidiq, R. Ridwan dan Y. Widyastuti. 2013. Kecernaan Bahan Kering dan Bahan Organik Silase Campuran Pennisetum Purpureum dan Acacia Villosa secara In Vitro. Prosiding Seminar Nasional dan Forum Komunikasi Industri Peternakan dalam Rangka Mendukung Kemandirian Daging dan Susu Nasional. Hal. 400-408.

Rahmaningtyas, I.H., R. Yulianto, D.D. Prastika, K. Arifin, V. Oktaviana, R.S. Setiabudi dan M.T.E. Purnama. 2017. Efektivitas Tepung Cirripedia sp. (Cirripedia Sp.) Terhadap Pertambahan Berat Badan dan Feed Convertion Ratio (FCR) ayam pedaging. Agroveteriner.5:2.

Raharjo, Y.C., dan B.R.A.M. Brahmantiyo. 2014. Plasma nutfah kelinci sebagai sumber pangan hewani dan produk lain bermutu tinggi. Indonesia Journal of Animal and Veterinary Sciences. Vol.19 (3).

Ridwan, M., dan A. Asnawi. 2008. Kajian Ekonomi Usaha Ternak Kelinci di Kelurahan Salokaraja Kelurahan Salokaraja Kabupaten Soppeng. Laporan Penelitian Dosen Muda. Fakultas Peternakan/Jurusan Sosial Ekonomi Peternakan Universitas Hasanuddin.

Rohimah. 2012. Kecernaan Nutrien pada Kelinci Peranakan New Zealand White Jantan yang Diberi Pellet Ransum Komplit Mengandung Indigofera zollingeriana dan Leucaena lucocephala [Skripsi]. Fakultas Peternakan. Institut Pertanian Bogor. Hal. 26.

Rukhmana. H. R., 2005. Prospek Beternak Kelinci.

Sarwono, B. 2004. Kelinci Potong dan Hias. Penerbit Agro Media Pustaka, Jakarta.

Subekti, E. 2009. Ketahanan pakan ternak Indonesia. MEDIAGRO. 5(2): 63-71.

Suprijatna, E., A. Umiyati dan K. Ruhyat, 2005. Ilmu Dasar Ternak Unggas. Penebar Swadaya. Jakarta.

Surbakti, T. J. V., M. Tafsin dan A. H. Daulay. 2014. Kecernaan Bahan Kering dan Bahan Organik Ransum yang Mengandung Pelepah Daun Kelapa Sawit dengan Perlakuan Fisik, Kimia, Biologi, dan Kombinasinya Pada Domba. Jurnal Peternakan Integratif. 3(1): 62-70.

Tilman, A. D., H. Hartadi, S. Reksodiprojo, S. Prawirokusumo dan S. Lebdosoekojo. 1998. Ilmu Makanan Ternak Dasar. Cetakan Keenam. Gajah Mada University Press. Yogyakarta.

Wardani, I.K. 2012. Pemanfaatan Limbah Pembuatan Tepung Beras sebagai Substitusi Jagung terhadap Daya Cerna Serat Kasar dan Bahan Organik Ayam Pedaging Jantan [Skripsi]. Fakultas Kedokteran Hewan. Universitas Airlangga.

Wijayanti, W. 2009. Pengaruh Substitusi Konsentrat dengan Tepung Daun Wortel dalam Ransum terhadap Kecernaan Kelinci Lokal Jantan [skripsi]. Fakultas Pertanian. Universitas Sebelas Maret. Surakarta. 